\title{
Azamora penicillana occurrence in sour passion fruit in the state of Minas Gerais
}

\author{
Victor Dias Pirovani ${ }^{1}$, Marilene Fancelli ${ }^{2}$, Bruno Magno Moreira ${ }^{3}$, \\ Luiz Flávio Vianna Silveira ${ }^{4}$, Dirceu Pratissoli ${ }^{5}$
}

\begin{abstract}
Azamora penicillana (Walker) (Lepidoptera: Pyralidae) is popularly known as exotic passionflower caterpillar, passionflower web, cloak or pouch. It is considered an emergent pest of passion fruit crop due to damages caused to the plant and management difficulties related to insect habit. This species is recorded for the first time infesting passion fruit in the state of Minas Gerais attacking leaves, fruits and branches. Pest attacks have been widely reported throughout the orchard.
\end{abstract}

Index terms: exotic passionflower caterpillar; Passiflora edulis; emergent pest.

\section{Ocorrência de Azamora penicillana em maracujazeiro-azedo no estado de Minas Gerais}

\begin{abstract}
Resumo -Azamora penicillana (Walker) (Lepidoptera: Pyralidae) é conhecida popularmente como lagarta exótica do maracujazeiro, de teia do maracujazeiro, do capote ou cartucheira. É uma praga emergente da cultura do maracujazeiro em função dos danos provocados à cultura e das dificuldades de manejo em função do hábito do inseto. Esta espécie é registrada pela primeira vez infestando a cultura do maracujazeiro, no Estado de Minas Gerais, atacando folhas, frutos e ramos. Os ataques da praga foram registrados de forma generalizada em todo o pomar.
\end{abstract}

Termos para indexação: lagarta exótica do maracujazeiro; Passiflora edulis; praga emergente.

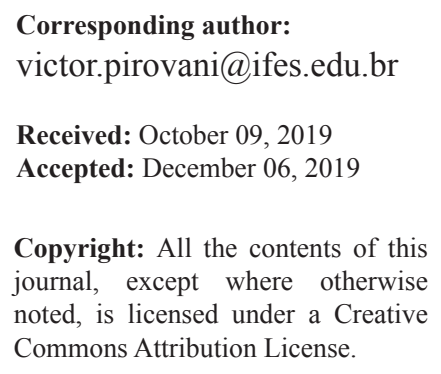

${ }^{1}$ Doctor - Professor of Instituto Federal do Espírito Santo, Campus de Alegre, Espírito Santo, Brasil. E-mail: victor.pirovani@ifes.edu.br ${ }^{\text {(ORCID }}$ 0000-0002-1143-4547)

${ }^{2}$ Doctor - Researcher at Empresa Brasileira de Pesquisa Agropecuária, Embrapa Mandioca e Fruticultura, Cruz das Almas, Bahia, Brasil. E-mail: marilene.fancelli@embrapa.br(ORCID 0000-0002-5004-1236)

${ }^{3}$ Agronomist Engineer - Administrative Technician of Instituto Federal de Minas Gerais, Campus São João Evangelista, Minas Gerais, Brasil. E-mail: bruno.moreira@ifmg.edu.br (ORCID 0000-0002-4398-1772)

${ }^{4}$ Doctor - Professor of Instituto Federal do Espírito Santo, Campus de Alegre, Espírito Santo, Brasil. E-mail: viannasilveira@gmail.com ${ }^{(O R I C D}$ 0000-0002-0739-3711)

${ }^{5}$ Doctor - Professor at Universidade Federal do Espírito Santo, Centro de Ciências Agrárias e Engenharias, Alegre, Espírito Santo, Brasil. E-mail: dirceu.pratissoli@gmail.com ${ }^{(O R C I D}$ 0000-0003-4485-1491) 
The genus Passiflora L., belonging to the Passifloraceae family, originates from South America, whose area with greater geographical distribution is located in the Center-North of Brazil (LOPES, 1991). It has over 530 species described for the genus, of which about 150 are native from Brazil (CROCHEMORE et al., 2003; FLORA DO BRASIL, 2020).

Worldwide, there are six species of mites and 91 insect species (distributed in seven orders) described as pests or associated with passion fruit (Passiflora edulis) culture (AGUIAR-MENEZES et al., 2002).

Among the pest insects, there is a moth about $2.5 \mathrm{~cm}$ wingspan and gray-brown color (Figure 1) (PRATISSOLI; CARVALHO, 2015) popularly known as exotic passionflower caterpillar, passionflower web, cloak or pouch [Azamora penicillana (Walker, 1863) (Lepidoptera: Pyralidae)] (FANCELLI, 1993).

This moth is an emerging pest for passion fruit plant related to crop damage and management difficulties due to its insect habit (PRATISSOLI; CARVALHO, 2015; FANCELLI, 1995).

The occurrence of A. penicillana is reported in the state of Bahia, in infestations in wild passion fruit (FANCELLI, 1993) and in the state of Espirito Santo, in sour passion fruit (PRATISSOLI; CARVALHO, 2015).
Damage caused by A. penicillana occurs in flowers, buds and young fruits, which significantly reduce yield. Moreover, it can cause burning in the passion fruit foliage as the caterpillars release a greenish-colored liquid with phytotoxic action. (MATTA; NASCIMENTO, 1976; FANCELLI, 1995).

A. penicillana caterpillars were observed infesting passion fruit (Passiflora edulis Sims.) crop in the Fruit Sector of the Federal Institute of Minas Gerais, São João Evangelista campus $\left(18^{\circ} 33^{\prime} 20.5^{\prime \prime} \mathrm{S}+42^{\circ} 45^{\prime} 05.5^{\prime \prime} \mathrm{W}\right)$, state of Minas Gerais in the 2015, 2016 and 2017 harvests.

Fruits and leaves of infested passion fruit (Figure 2) were transported to the Entomology Laboratory of the Federal Institute of Minas Gerais, São João Evangelista campus and packed in plastic pots with moistened sand to obtain the adults. After this period, the adults were assembled and identified.

Thus, the occurrence of $A$. penicillana is recorded for the first time in passion fruit crops in the state of Minas Gerais.

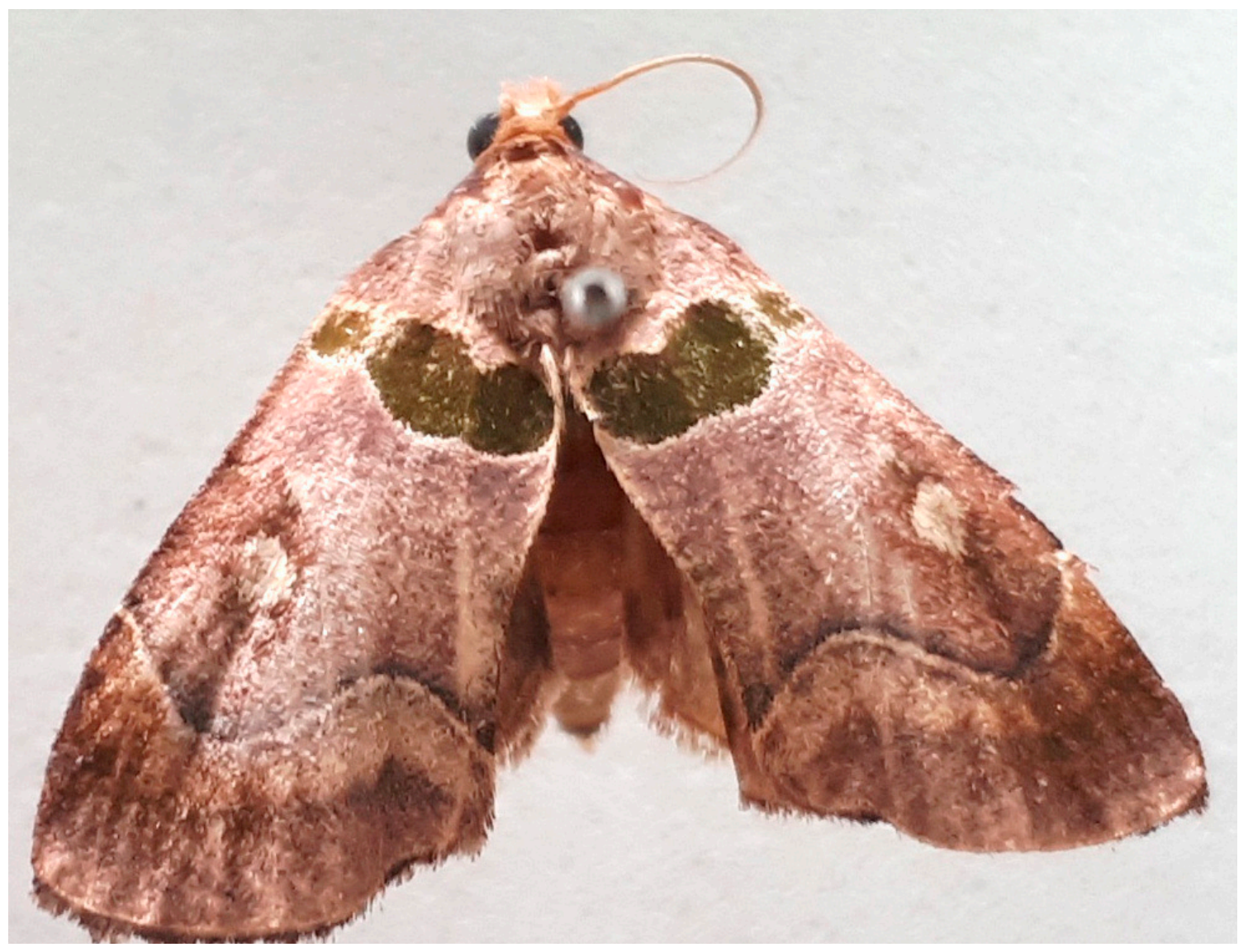

Figure 1. Adult of Azamora penicillana. 


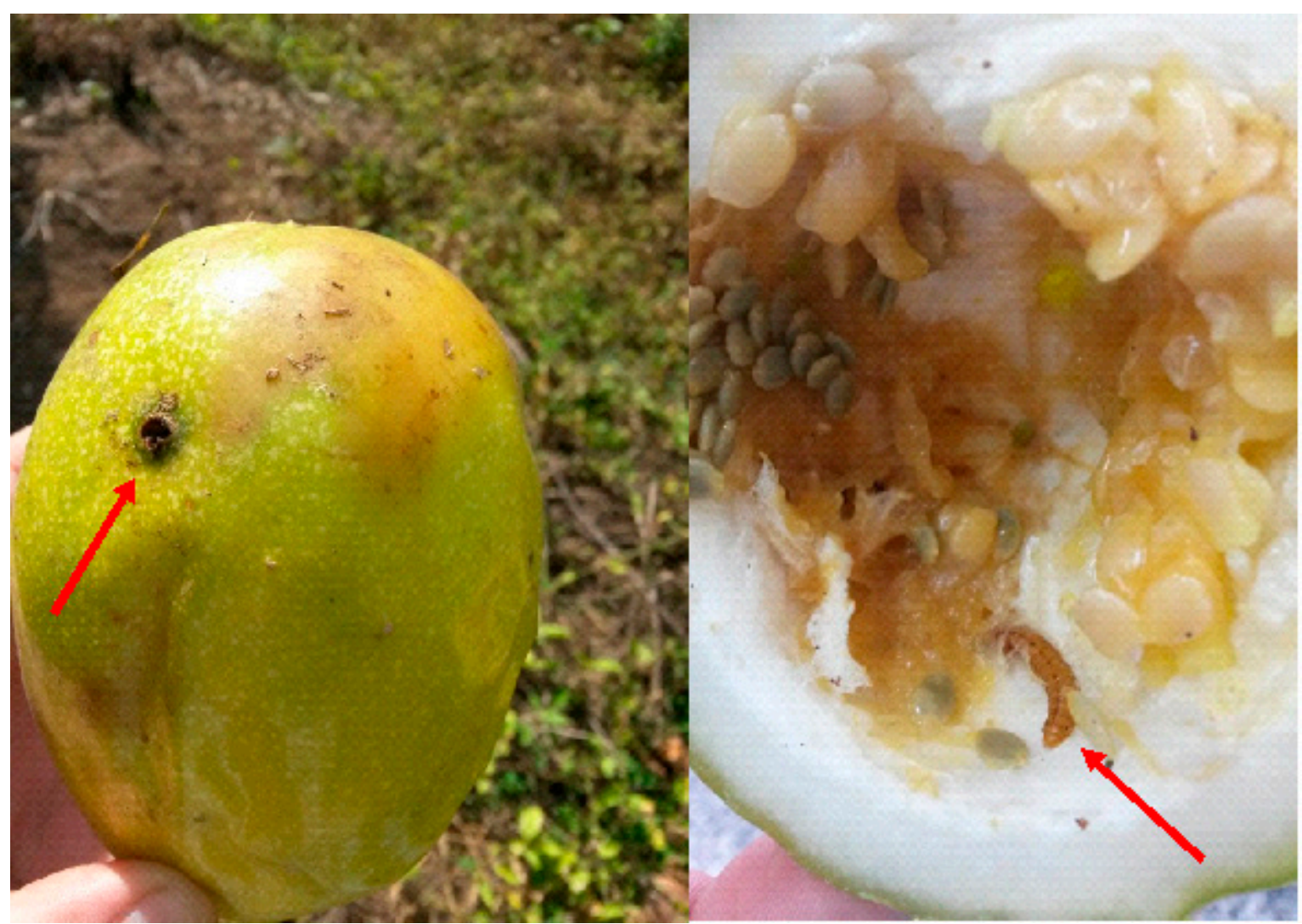

Figure 2. Passion fruit infested with Azamora penicillana.

\section{References}

AGUIAR-MENEZES, L.E.; MENEZES, E.B.; CASSINO, P.C.R.; SOARES, M.A. Passion fruit. In: PENÃ, J. E; SHARP, J.L.; WYSOKI, M. (ed.). Tropical fruit pests and pollinators: biology, economic importance, natural enemies and control. Wallingford, UK: CAB International, 2002. p.361-390.

CROCHEMORE, M.L.; MOLINARI, H.B.; STENZEL, N.M.C. Caracterização agromorfológica do maracujazeiro (Passiflora spp.). Revista Brasileira de Fruticultura, Jaboticabal, v.25, n.1, p.5-10, 2003.

FANCELLI, M. A lagarta de teia do maracujazeiro. Cruz das Almas: Embrapa-CNPMF, 1995. 2p. (Maracujá em Foco, 54).

FANCELLI, M. Ocorrência de Azamora penicillana (Walk.) (Pyralidae, Chrysauginae) em maracujá silvestre. Anais da Sociedade Entomológica do Brasil, Londrina, v. 22, n.2, p.389-390, 1993.
LOPES, S.C. Citogenética do maracujá, Passiflora spp. In: SÃO JOSÉ, A.R. A cultura do maracujá no Brasil. Jaboticabal: FUNEP, 1991. p. 201-209.

MATTA, E.A.; NASCIMENTO, A.S. Um novo microlepidóptero como praga do maracujazeiro Passiflora edulis var. flavicarpa, na Bahia - Brasil. Anais da Sociedade Entomológica do Brasil, Londrina, n.5, p.143146, 1976.

FLORA DO BRASIL 2020 em construção. Passiflora. Rio de Janeiro: Jardim Botânico, 2019. Disponível em: http:// reflora.jbrj.gov.br/reflora/floradobrasil/FB12506. Acesso em: 23 mai. 2019.

PRATISSOLI, D.; CARVALHO, J.R. Lagartas exóticas do maracujazeiro. In: PRATISSOLI, D. (org.). Pragas emergentes no estado do Espírito Santo. Alegre: Unicopy, 2015, v.1, p.106-111. 